\title{
EFFECT OF OXYTOCIN ON SPERM FUNCTION AND SEMINAL BIOCHEMISTRY OF ASTHENOSPERMIC PATIENTS
}

\author{
Adnan S. Al-Janabi*, Ferial A. Al-Mehdawi** and Makarim Q.Al-Lami** \\ * University of Al-Nahrain, Baghdad, Iraq. \\ **Department of Biology, College of Science, University of Baghdad, Baghdad, Iraq.
}

\begin{abstract}
Semen samples of 90 asthenospermic patients were examined, then they were divided into three main equal groups. In the first group, Oxytocin (OT) addition in three concentrations (2, 4, and 6 $\mathrm{IU} / \mathrm{ml}$ ) with sperm preparation medium (SPM) to the semen samples was investigated. Changes in sperm function tests and seminal biochemistry was used as indicator of effect. Results indicated that a significant increase in sperm grade activity in $2 \mathrm{IU} / \mathrm{ml}$ OT with a tendency for a decrease in this motility parameter in higher OT concentration. Concentration $2 \mathrm{IU} / \mathrm{ml}$ of OT was applied with SPM and without in the second and third groups, respectively. In presence of SPM, a significant increase in the sperm motility characteristics (the percentage of sperm motility and sperm grade activity) was observed. While when SPM was absent, non-significant change in these parameters was seen. These findings indicate that OT at the concentration of $2 \mathrm{IU} / \mathrm{ml}$ has got a stimulatory effect on sperm motility characteristics. Using of SPM potentiated this effect of OT.

Total protein (TP), cholesterol, calcium, creatine kinase (CK), and fructose were measured in the seminal plasma and in the supernatant of sperm suspension of OT-treated and control samples. According to the results, a high significant increase in cholesterol was found in the external medium, this may be attributed to loss of cholesterol from the plasma membrane of the sperm. Also, OT may modify cellular calcium transport across the plasma membrane, resulting in high intracellular calcium concentration and a high significant decrease in level of calcium in the external medium. In addition to a high significant decrease in fructose level of the external medium.
\end{abstract}

Key words: Oxytocin, Seminal biochemistry, Sperm function, Asthenospermia.

\section{Introduction}

Asthenospermia indicates a significant reduction in sperm motility which is an important parameter in evaluating the fertilizing potential of the semen ${ }^{(1)}$. A number of factors may be responsible for reduced sperm motility such as: spermatozoal defects, genital tract infection, partial ductal obstruction, spinal cord injury, sperm agglutination, and antisperm antibodies ${ }^{(2 ; 3)}$. For several decades attempts have been made to improve the motility of hypokinetic specimens by using various means, one of them is the addition of motilitystimulating agents to the ejaculate prior to its use for artificial insemination. These agents include: hormonal compounds such as progesterone $^{(4)}$, human chorionic gonadotropin $^{(5)}$, $\operatorname{relaxin}^{(6) ;}$ non - hormonal substances such as pentoxifyllin ${ }^{(7)}$, caffeine ${ }^{(8)}$, cAMP $^{(9)}$.

Oxytocin (OT) is produced, in the male mammal, in similar quantities as in the female. Little is known about its physiology ${ }^{(10)}$. Majority of investigations was performed in vivo to study the physiological role of this hormone in the male. For these reasons, we tried in this work to study the effect of OT (as a natural product) on human sperm activation and to explain the proposed mechanisms in which it affects. Such an effect which is probably being a new concept will open the way for helping asthenospermic patients to have their sperm activated using naturally produced material.

In this study we investigate the influence of OT on semen parameters of asthenospermic patients, and exploring the best concentration of 
OT that harvests a maximal number of motile spermatozoa.

\section{Materials and Methods}

Semen samples were obtained from 90 asthenospermic patients attending the Institute of Embryo Research and Infertility Treatment, University of Al-Nahrain. All samples were collected by masturbation after 3-4 days of sexual abstinence, then they were placed in an incubator at $37^{\circ} \mathrm{C}$, waiting for liquefaction.

The medicult sperm preparation medium (SPM) was used for sperm activation in vitro. Oxytocin (OT) used in this study was provided in $50 \mathrm{ml}$ vials (10 IU OT/ml). Normal saline $(0.9 \% \mathrm{NaCl})$ was used for preparation of three concentrations of OT $(2,4$, and $6 \mathrm{IU} / \mathrm{ml})$.

\section{Seminal Fluid Analysis (SFA):}

Seminal standard parameters following World Health Organization guidelines ${ }^{(11)}$ were determined on all samples which including physical parameters (liquefaction time, $\mathrm{pH}$, volume) as well as using light microscopy to determine sperm concentration, sperm motility percent and grade of activity, sperm abnormality percent, leukocytes and phagocytes concentrations, and sperm agglutination.

\section{Oxytocin and Sperm Function Tests:}

Semen samples were mixed with OT and $\mathrm{SPM}^{(12)}$. For each concentration of OT $(2,4$, and $6 \mathrm{IU} / \mathrm{ml}$ ), a culture tube was prepared, and 0.4 $\mathrm{ml}$ of SPM was mixed with $0.1 \mathrm{ml}$ of each concentration, then $0.5 \mathrm{ml}$ of semen sample was added to each tube. After shaking the contents, the tubes were incubated in $5 \% \mathrm{CO}_{2}$ incubator at $37{ }^{\circ} \mathrm{C}$ for 30 minutes, then a drop of the mixture was aspirated by micropipette to be examined under 40X objective lens to study the effect of OT at these concentrations on the sperm function tests. Ten semen samples were studied for each concentration of OT. Each concentration was compared with semen samples treated with normal saline as control $(\mathrm{OT}=0 \mathrm{IU} / \mathrm{ml})$, so that the total number of patients examined in this experiment was 30 (1st group).
Based on the outcome of this experiment, OT at $2 \mathrm{IU} / \mathrm{ml}$ was tried, as shown above, with SPM and without in the 2nd and 3rd groups, respectively. Each group involved 30 semen samples. The results were compared with the control samples in which normal saline was used instead of OT.

\section{The Seminal Biochemical Study:}

Seminal plasma was obtained by centrifugation of liquefied semen samples at $3000 \mathrm{rpm}$ for 15 minutes, the sperm-free seminal plasma was then aspirated and kept in a clean tube until time of analysis. Following examination of sperm suspension microscopically, the samples were centrifuged at 3000 rpm for 15 minutes, then the supernatant was isolated and kept in a clean tube until time of analysis.

Five biochemical parameters were evaluated, these are: total protein (TP), cholesterol, calcium, creatine kinase $(\mathrm{CK})$, and fructose. These parameters were measured in the seminal plasma of sixty patients. Also, they were measured after addition of OT at the concentration of $2 \mathrm{IU} / \mathrm{ml}$ in the supernatant of sperm suspension of control and OT-treated samples. The biochemical parameters were measured as the following:

1.Total Protein: Total protein was determined according to the Biuret method reported by Silverman et al. ${ }^{(13)}$, Linear kit was used in this colorimetric method.

2.Cholesterol: Cholesterol concentration was determined according to the method of Richmond $^{(14)}$, Linear kit was used in this enzymatic colorimetric method.

3.Calcium: Calcium concentration was estimated applying the method reported by Baginski et $a l^{(15)}$, kit of Giesse was used in this colorimetric method.

4.Creatine Kinase: Kinetic determination method was followed in estimation of $\mathrm{CK}$ activity $^{(16)}$. Enzyme activity was assayed with Syrbio kit. 
5.Fructose: Fructose level was estimated according to the method of Mann ${ }^{(17)}$.

\section{Statistical Analysis}

The statistical analysis was performed using the Statistical Package for Social Sciences (SPSS), version 10.5, computer software. All data were expressed as mean \pm SD. Statistical comparisons between groups were made using student's-test and a $\mathrm{P}$ value of $<0.05$ was considered significant. Differences between groups were analyzed using an analysis of variance (ANOVA), the significance level was set at $\mathrm{P}<0.05^{(18)}$.

\section{Results}

\section{Seminal Fluid Analysis:}

The physical characteristics of the semen samples (Table 1) revealed that mean of liquefaction time was on the maximal side of the normal value, while mean of semen volume was on the minimal side of the normal value. All semen samples had normal alkaline $\mathrm{pH}$, which was within the normal limit. Sperm concentration was within the normal limit, while the percentage of motile sperm was below the normal limit, also, mean of sperm grade activity was below the normal range of Macleod scale.

The percentage of sperm abnormality was on the maximal side of the normal limit. The percentage of sperm agglutination was above the normal limit. Regarding seminal fluid infection, the results revealed that, the concentrations of leukocytes and phagocytes were above WHO normal limit.

Table (1)

Semen physical characteristics of the patients.

\begin{tabular}{||l||c||c||}
\hline \multicolumn{1}{|c||}{ Semen Characters } & Value (Mean \pm SD) & Normal Values \\
\hline \hline Liquefaction time (minute) & $35.17 \pm 8.46$ & $<30$ \\
\hline \hline Semen volume $(\mathrm{ml})$ & $2.50 \pm 0.93$ & $2-6 \mathrm{ml}$ \\
\hline \hline $\mathrm{pH}$ & $7.84 \pm 0.15$ & $7.4-8.2$ \\
\hline \hline Sperm concentration (million/ml) & $44.20 \pm 20.53$ & $>20$ \\
\hline Sperm motility $(\%)$ & $34.66 \pm 11.32$ & $>60$ \\
\hline \hline Grade of activity $(\mathrm{Macleod}$ scale) & $1.62 \pm 0.44$ & $<5$ \\
\hline \hline Sperm abnormality $(\%)$ & $48.82 \pm 8.65$ & Negative \\
\hline Sperm agglutination $(\%)$ & $3.72 \pm 2.14$ & $<1$ \\
\hline \hline Leukocytes concentration $(\mathrm{million} / \mathrm{ml})$ & $2.52 \pm 1.19$ & $<0.5$ \\
\hline \hline Phagocytes concentration $(\mathrm{million} / \mathrm{ml})$ & $2.86 \pm 1.44$ & $<0$ \\
\hline \hline
\end{tabular}

\section{Effect of Oxytocin on Sperm Function Tests:}

Results shown in (Table 2) indicated that addition of OT at 2, 4, and $6 \mathrm{IU} / \mathrm{ml}$ did not cause any significant change $(\mathrm{P}>0.05)$ in all sperm function tests except the grade of activity which rose significantly $(\mathrm{P}<0.05)$ at the concentration of $2 \mathrm{IU} / \mathrm{ml}$ in comparison with the control samples. 
Table (2)

Effect of different concentrations of oxytocin $(2,4$, and $6 \mathrm{IU} / \mathrm{ml})$ on sperm function tests.

\begin{tabular}{|c|c|c|c|c|c|c|}
\hline Parameters & $\begin{array}{l}\stackrel{0}{O} \\
\stackrel{\underline{\theta}}{0} \\
\underline{0}\end{array}$ & 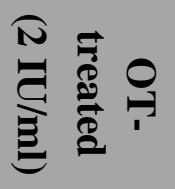 & $\stackrel{0}{\stackrel{0}{E}}$ & 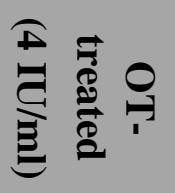 & $\overbrace{\mathscr{E}}^{\varrho}$ & 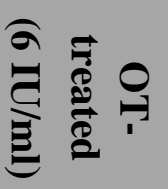 \\
\hline Sperm concentration (million/ml) & $\begin{array}{c}35.20 \\
\pm \\
13.59\end{array}$ & $\begin{array}{c}35.50 \\
\pm \\
13.57\end{array}$ & $\begin{array}{c}30.60 \\
\pm \\
10.31\end{array}$ & $\begin{array}{c}30.90 \\
\pm \\
10.63\end{array}$ & $\begin{array}{c}32.90 \\
\pm \\
12.28\end{array}$ & $\begin{array}{c}33.50 \\
\pm \\
12.40\end{array}$ \\
\hline Sperm motility (\%) & $\begin{array}{c}58.40 \\
\pm \\
10.73\end{array}$ & $\begin{array}{c}58.72 \\
\pm \\
9.22\end{array}$ & $\begin{array}{c}48.55 \\
\pm \\
8.18\end{array}$ & $\begin{array}{c}49.00 \\
\pm \\
8.10\end{array}$ & $\begin{array}{c}48.72 \\
\pm \\
9.11\end{array}$ & $\begin{array}{c}47.84 \\
\pm \\
9.34\end{array}$ \\
\hline Grade of activity & $\begin{array}{c}2.62 \\
\pm \\
0.34\end{array}$ & $\begin{array}{c}2.98^{*} \\
\pm \\
0.38\end{array}$ & $\begin{array}{c}2.56 \\
\pm \\
0.26\end{array}$ & $\begin{array}{c}2.54 \\
\pm \\
0.24\end{array}$ & $\begin{array}{c}2.46 \\
\pm \\
0.22\end{array}$ & $\begin{array}{c}2.43 \\
\pm \\
0.23\end{array}$ \\
\hline Sperm abnormality (\%) & $\begin{array}{c}48.45 \\
\pm \\
5.12\end{array}$ & $\begin{array}{c}49.00 \\
\pm \\
4.58\end{array}$ & $\begin{array}{c}45.10 \\
\pm \\
4.63\end{array}$ & $\begin{array}{c}44.50 \\
\pm \\
4.48\end{array}$ & $\begin{array}{c}48.14 \\
\pm \\
5.35\end{array}$ & $\begin{array}{c}48.50 \\
\pm \\
4.86\end{array}$ \\
\hline Sperm agglutination $(\%)$ & $\begin{array}{c}2.12 \\
\pm \\
1.39\end{array}$ & $\begin{array}{c}2.18 \\
\pm \\
1.42\end{array}$ & $\begin{array}{c}2.20 \\
\pm \\
1.50\end{array}$ & $\begin{array}{c}2.00 \\
\pm \\
1.67\end{array}$ & $\begin{array}{c}2.15 \\
\pm \\
1.60\end{array}$ & $\begin{array}{c}2.15 \\
\pm \\
1.58\end{array}$ \\
\hline Leukocytes concentration (million/ml) & $\begin{array}{c}1.20 \\
\pm \\
0.79\end{array}$ & $\begin{array}{c}1.20 \\
\pm \\
0.92\end{array}$ & $\begin{array}{c}1.32 \\
\pm \\
0.68\end{array}$ & $\begin{array}{c}1.22 \\
\pm \\
0.68\end{array}$ & $\begin{array}{c}1.20 \\
\pm \\
1.03\end{array}$ & $\begin{array}{c}1.10 \\
\pm \\
0.94\end{array}$ \\
\hline Phagocytes concentration (million/ml) & $\begin{array}{c}2.00 \\
\pm \\
0.92\end{array}$ & $\begin{array}{c}1.90 \\
\pm \\
1.00\end{array}$ & $\begin{array}{c}1.92 \\
\pm \\
1.20\end{array}$ & $\begin{array}{c}1.68 \\
\pm \\
0.98\end{array}$ & $\begin{array}{c}1.40 \\
\pm \\
1.11\end{array}$ & $\begin{array}{c}1.20 \\
\pm \\
0.95\end{array}$ \\
\hline Number of samples & \multicolumn{2}{|c|}{10} & \multicolumn{2}{|r|}{10} & \multicolumn{2}{|r|}{10} \\
\hline
\end{tabular}

Values are means \pm standard deviation of means. *Significant difference $(P<0.05)$.

\section{Effect of Oxytocin on Sperm Function Tests}

Addition of OT $(2 \mathrm{IU} / \mathrm{ml})$ to the semen revealed that, in presence of SPM (Table 3), there were a high significant decrease $(\mathrm{P}<0.001)$ in sperm concentration and a significant increase $(\mathrm{P}<0.05)$ in the percentage of sperm motility and sperm grade activity after activation for the control and OT-treated samples as compared to their values before activation. The percentage of sperm motility and sperm grade activity significantly improved $(\mathrm{P}<0.05)$ after the application of OT $(2 \mathrm{IU} / \mathrm{ml})$ as compared with the control samples. When SPM was absence (Table 4), a high significant decrease $(\mathrm{P}<0.001)$ was observed in sperm concentration in the two groups as compared to their values before activation. An increase 
(although it is not significant) was observed in the percentage of sperm motility and sperm grade activity only for the OT-treated samples. When a comparison was made between the same activation technique with or without SPM, no significant difference $(\mathrm{P}>0.05)$ was found in regard to sperm concentration between the two preparation techniques (Fig.1). A significant improvement $(\mathrm{P}<0.05)$ was registered in the percentage of sperm motility and sperm grade activity when SPM was used (Fig. 2 and 3). While no significant differences $(\mathrm{P}>0.05)$ were observed in the other sperm parameters as shown in (Figs. 4, 5, 6 and 7).

Table (3)

Effect of oxytocin (2 IU/ml) on sperm function tests following sperm activation with sperm preparation medium.

\begin{tabular}{|l|c||c|c||}
\hline \multirow{2}{*}{\multicolumn{1}{|c|}{ Sperm function tests }} & \multirow{2}{*}{ Before activation } & \multicolumn{2}{c||}{ After activation } \\
\cline { 3 - 4 } & & Control & OT-treated \\
\hline \hline Sperm concentration (million/ml) & $45.60 \pm 15.95$ & $32.30^{\mathrm{a}^{* *}} \pm 13.20$ & $32.93^{\mathrm{a}^{* *}} \pm 12.82$ \\
\hline Sperm motility (\%) & $30.93 \pm 12.17$ & $37.70^{\mathrm{a}^{*}} \pm 14.49$ & $40.78^{\mathrm{b}^{*}} \pm 14.27$ \\
\hline \hline Grade of activity & $1.61 \pm 0.41$ & $2.06^{\mathrm{a}^{*}} \pm 0.44$ & $2.48^{\mathrm{b}^{*}} \pm 0.46$ \\
\hline Sperm abnormality (\%) & $49.87 \pm 9.70$ & $48.83^{\mathrm{a}} \pm 11.32$ & $48.66^{\mathrm{a}} \pm 11.36$ \\
\hline \hline Sperm agglutination (\%) & $3.82 \pm 2.84$ & $3.24^{\mathrm{a}} \pm 1.84$ & $3.36^{\mathrm{a}} \pm 1.54$ \\
\hline $\begin{array}{l}\text { Leukocytes concentration } \\
\text { (million/ml) }\end{array}$ & $2.02 \pm 1.30$ & $1.92^{\mathrm{a}} \pm 0.84$ & $1.82^{\mathrm{a}} \pm 0.94$ \\
\hline $\begin{array}{l}\text { Phagocytes concentration } \\
\text { (million/ml) }\end{array}$ & $2.33 \pm 1.42$ & $2.16^{\mathrm{a}} \pm 0.90$ & $2.24^{\mathrm{a}} \pm 0.88$ \\
\hline
\end{tabular}

Values are means \pm standard deviation of means. *Significant difference $(P<0.05) . *$ Significant difference $(P<0.001)$. Means carrying similar small letters indicate a non-significant difference $(P>0.05)$. Means carrying different small letters indicate a significant difference $(P<0.001)$.

Table (4)

Effect of oxytocin (2 IU/ml) on sperm function tests following sperm activation without sperm preparation medium.

\begin{tabular}{|l|c|c|c||}
\hline \multicolumn{1}{|c|}{ Sperm function tests } & \multirow{2}{*}{ Before activation } & \multicolumn{2}{c|}{ After activation } \\
\cline { 3 - 5 } & & Control & OT-treated \\
\hline \hline Sperm concentration (million/ml) & $43.53 \pm 14.95$ & $31.27^{* *} \pm 12.38$ & $31.53^{* *} \pm 12.73$ \\
\hline Sperm motility (\%) & $30.00 \pm 12.36$ & $30.07 \pm 10.69$ & $31.66 \pm 11.54$ \\
\hline Grade of activity & $1.60 \pm 0.43$ & $1.63 \pm 0.56$ & $1.72 \pm 0.58$ \\
\hline Sperm abnormality (\%) & $50.73 \pm 6.61$ & $49.79 \pm 6.97$ & $49.57 \pm 6.20$ \\
\hline Sperm agglutination (\%) & $3.42 \pm 2.45$ & $3.14 \pm 1.95$ & $3.22 \pm 1.85$ \\
\hline Leukocytes concentration (million/ml) & $2.23 \pm 1.53$ & $2.12 \pm 0.84$ & $2.15 \pm 0.72$ \\
\hline Phagocytes concentration (million/ml) & $2.47 \pm 1.38$ & $2.42 \pm 0.92$ & $2.48 \pm 0.89$ \\
\hline
\end{tabular}

Values are means \pm standard deviation of means. **Significant difference $(P<0.001)$. 


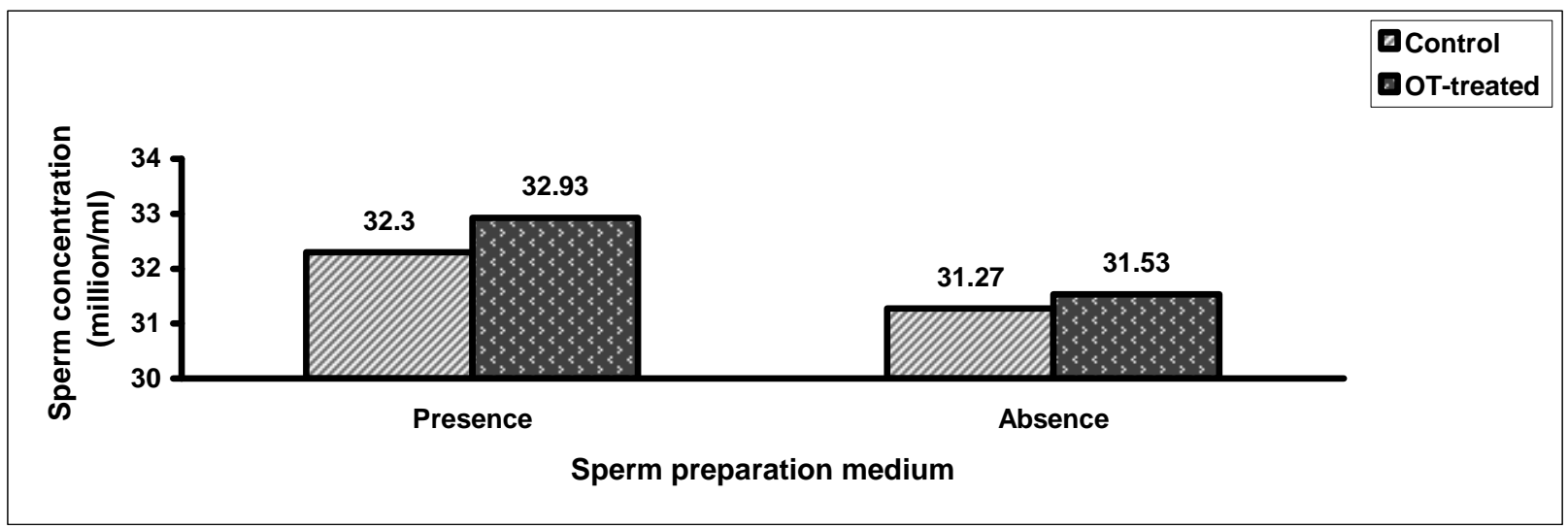

Fig.(1) : Sperm concentration of the control and OT-treated samples following sperm activation divided according to presence and absence of sperm preparation medium.

- Non-significant difference $(P>0.05)$ from corresponding group.

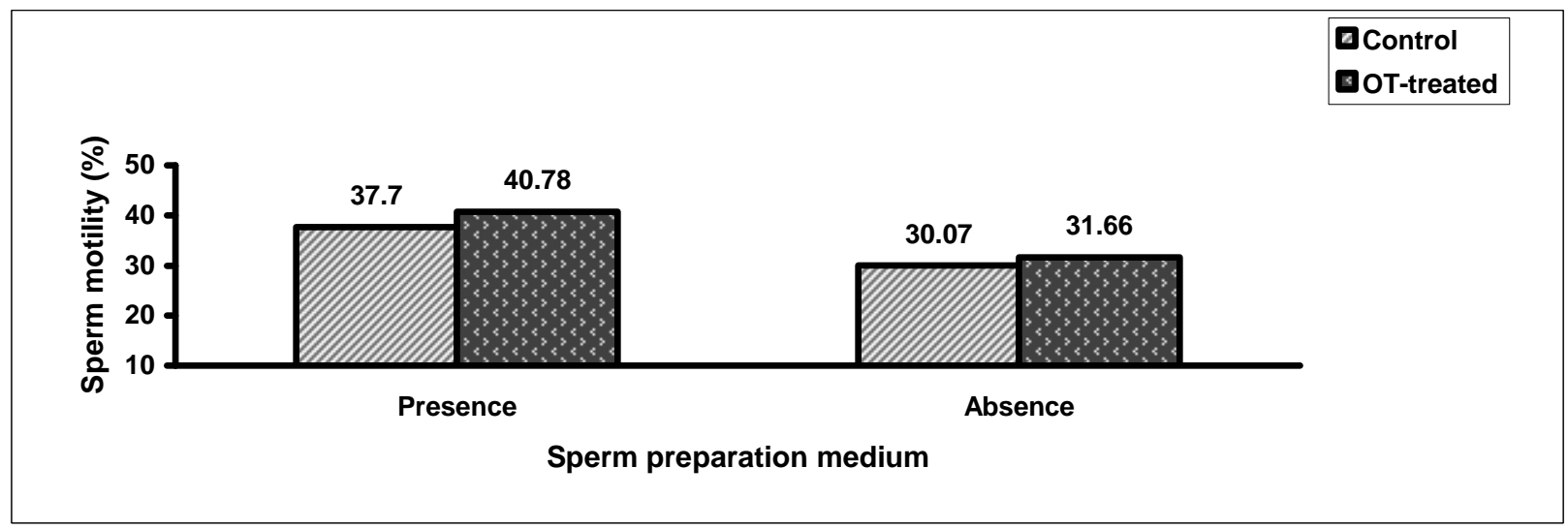

Fig. (2): The percentage of sperm motility of the control and OT-treated samples following sperm activation divided according to presence and absence of sperm preparation medium.

•* Significant difference $(\mathbf{P}<0.05)$ from corresponding group.

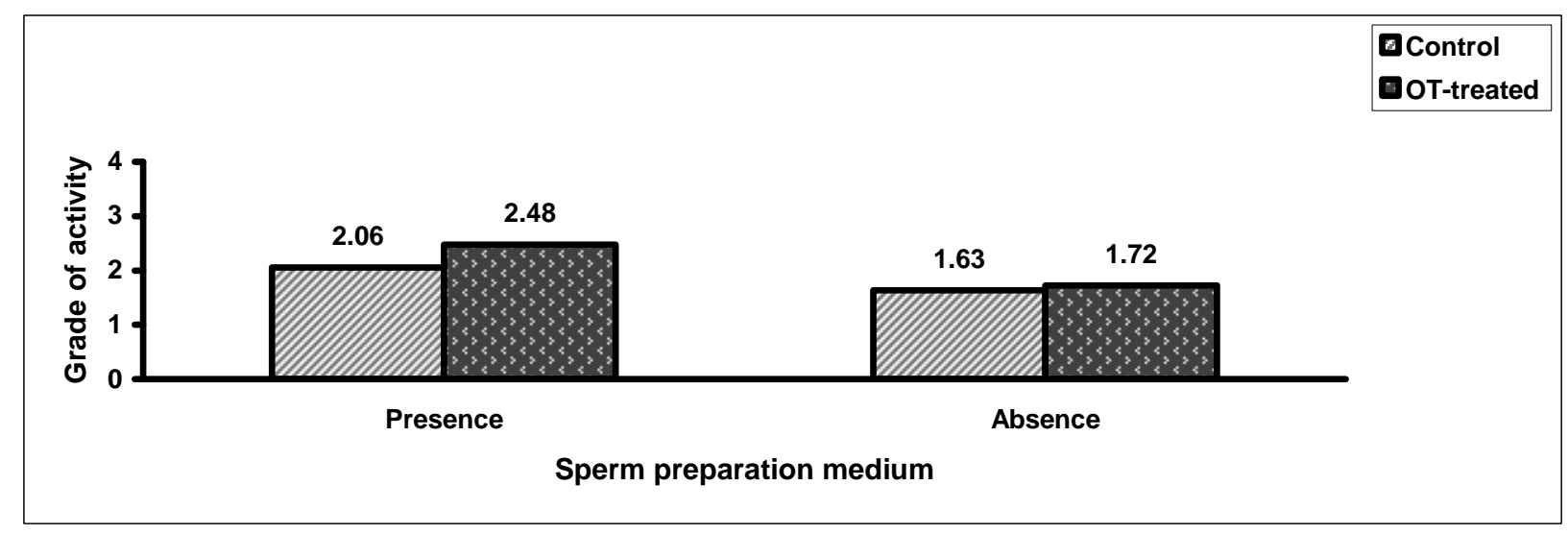

Fig. (3) : Sperm grade activity of the control and OT-treated samples following sperm activation divided according to presence and absence of sperm preparation medium.

•*Significant difference $(\mathbf{P}<\mathbf{0 . 0 5})$ from corresponding group. 


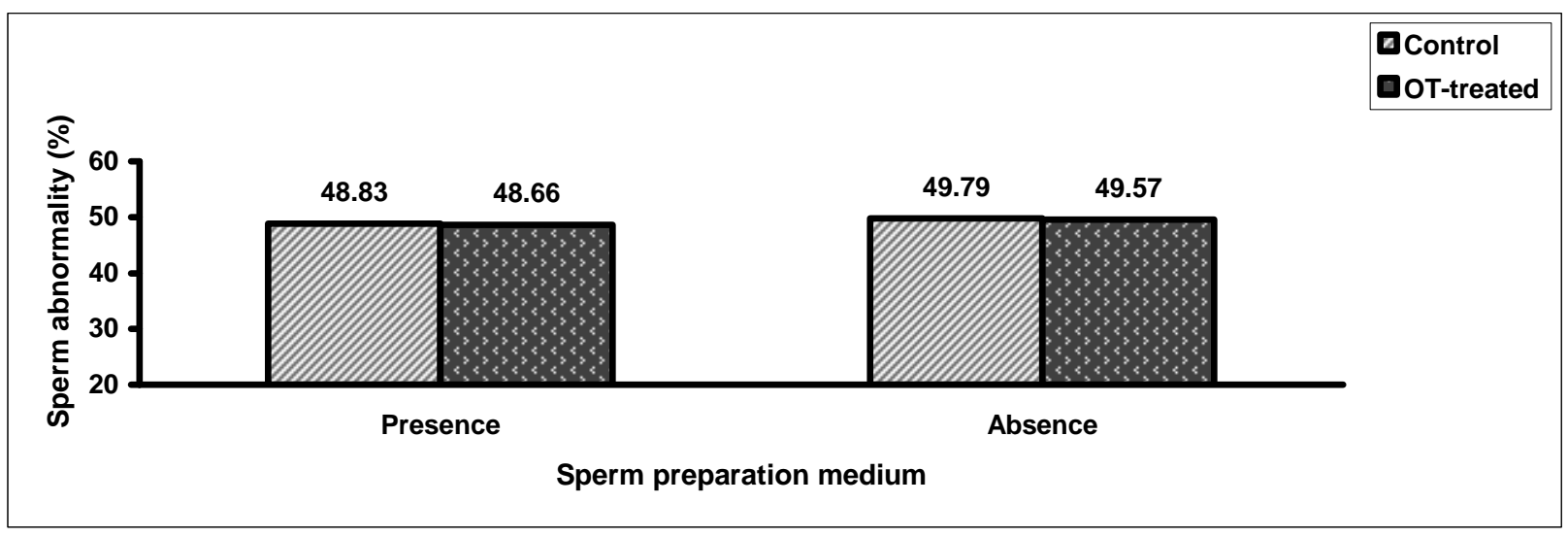

Fig. (4) :The percentage of sperm abnormality of the control and OT-treated samples following sperm activation divided according to presence and absence of sperm preparation medium.

- Non-significant difference $(P>0.05)$ from corresponding group.

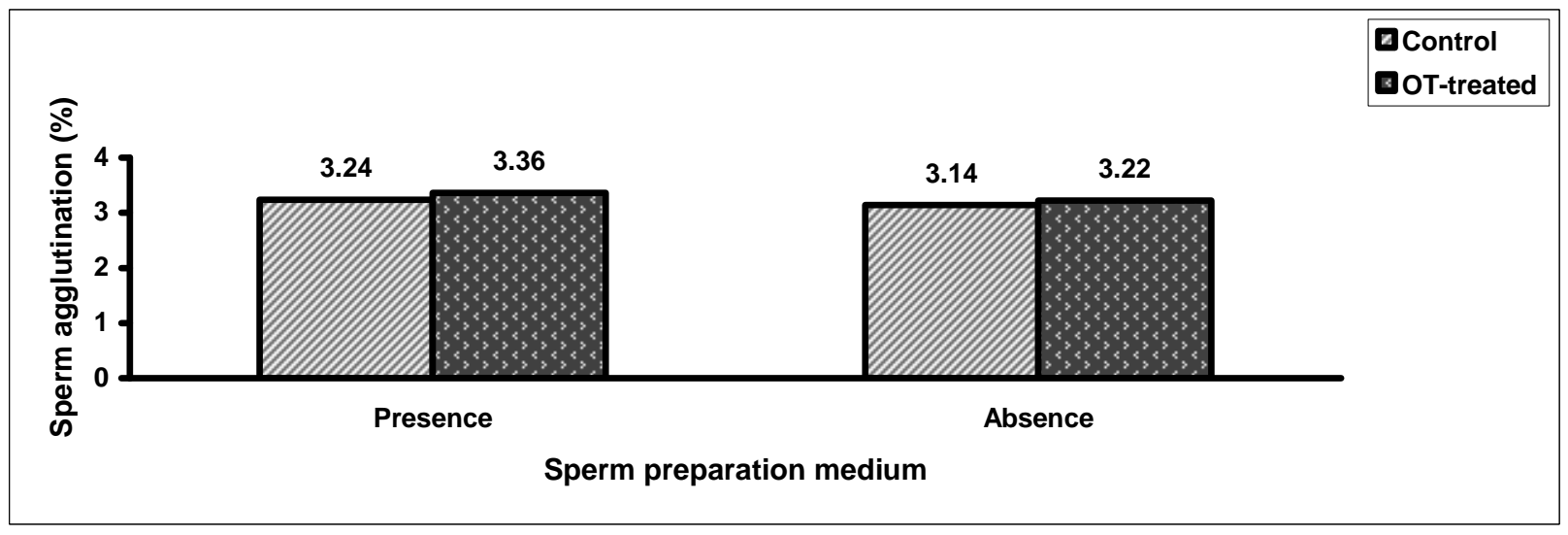

Fig. (5) :The percentage of sperm agglutination of the control and OT-treated samples following sperm activation divided according to presence and absence of sperm preparation medium.

- Non-significant difference $(P>0.05)$ from corresponding group.

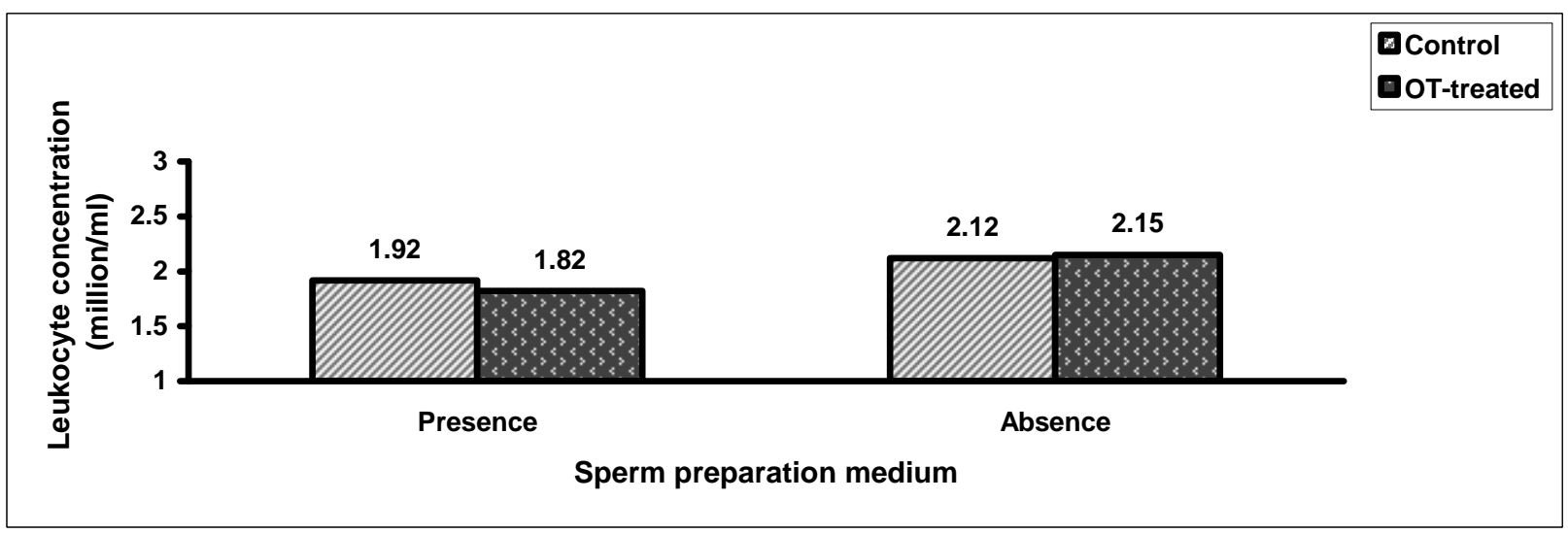

Fig. (6) : Leukocytes concentration of the control and OT-treated samples following sperm activation divided according to presence and absence of sperm preparation medium.

-Non-significant difference $(P>0.05)$ from corresponding group. 


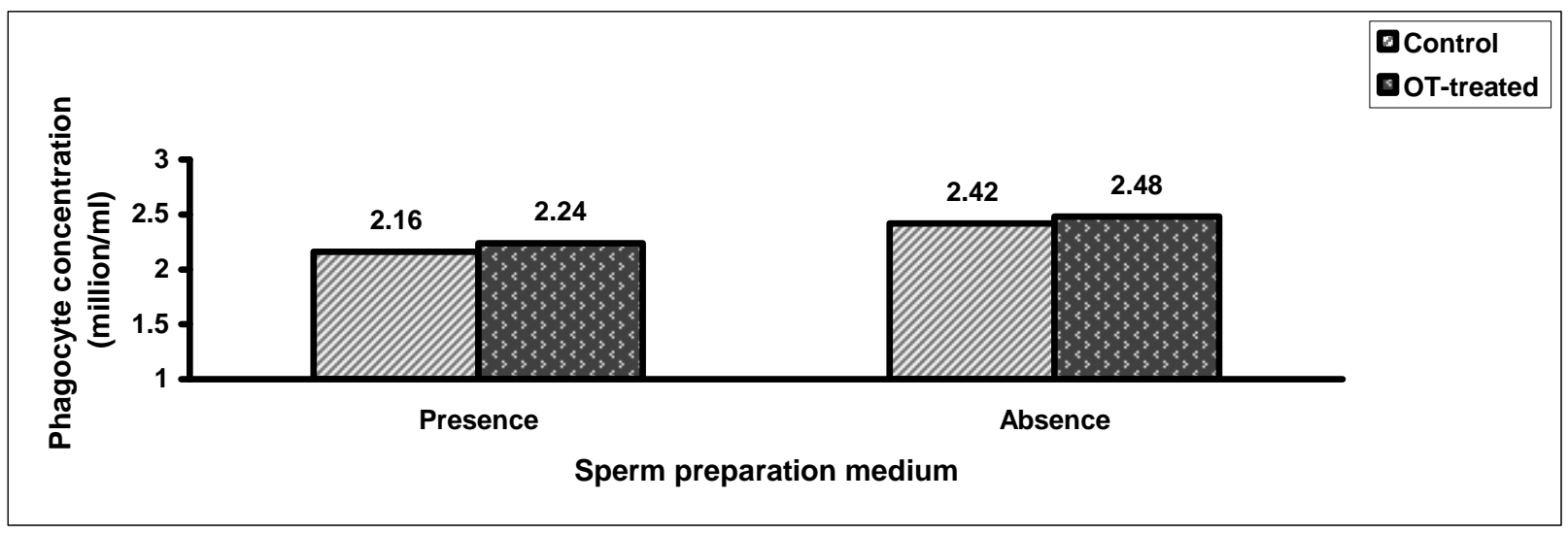

Fig. (7) : Phagocytes concentration of the control and OT-treated samples following sperm activation divided according to presence and absence of sperm preparation medium.

- Non-significant difference $(P>0.05)$ from corresponding group.

\section{Effect of Oxytocin (2 IU/ml) on The Seminal}

\section{Biochemical Parameters:}

In presence of SPM (Table 5), all the biochemical parameters significantly decreased $(\mathrm{P}<0.001)$ after sperm activation in control and OT-treated samples as compared to their values before activation. When these biochemical parameters were compared between the OTtreated samples and control samples, the results revealed that there was no significant difference $(\mathrm{P}>0.05)$ in level of TP and CK in the OTtreated samples versus the control samples, while there was a high significant increase $(\mathrm{P}<0.001)$ in level of cholesterol, and a high significant decrease $(\mathrm{P}<0.001)$ in level of both calcium and fructose in the OT-treated samples versus the control samples.

Table (5)

Effect of Oxytocin $(2 \mathrm{IU} / \mathrm{ml})$ on the seminal biochemical parameters following sperm activation with sperm preparation medium.

\begin{tabular}{|c|c|c|c|}
\hline \multirow{2}{*}{ Biochemical parameters } & \multirow{2}{*}{ Before activation } & \multicolumn{2}{|c|}{ After activation* } \\
\hline & & Control & OT-treated \\
\hline Total Protein $(\mathrm{g} / 100 \mathrm{ml})$ & $4.62 \pm 0.65$ & $2.85 \pm 0.34$ & $2.92 \pm 0.39$ \\
\hline Cholesterol (mg/100ml) & $31.49 \pm 12.50$ & $20.15 \pm 8.04$ & $23.65^{* *} \pm 8.75$ \\
\hline Calcium (mg/100ml) & $16.75 \pm 6.78$ & $12.68 \pm 3.76$ & $10.12^{* *} \pm 3.14$ \\
\hline Creatine Kinase (IU/L) & $218.23 \pm 48.44$ & $164.20 \pm 39.56$ & $165.20 \pm 39.38$ \\
\hline Fructose (mg/100ml) & $250.07 \pm 63.93$ & $184.58 \pm 43.20$ & $180.42^{* *} \pm 43.16$ \\
\hline
\end{tabular}

Values are means \pm standard deviation of means. *Significant differences $(P<0.001)$ in all the biochemical parameters between before and after activation. $*$ Significant difference $(P<0.001)$. 
In absence of SPM (Table 6), a high significant decrease $(\mathrm{P}<0.001)$ was also observed in all the biochemical parameters in control and OTtreated samples as compared to their values before activation. Effect of OT on the biochemical parameters was obvious as a slight increase and a slight decrease(non-significant) in levels of cholesterol and calcium, respectively, of OT-treated samples as compared with control samples. While level of fructose in the OTtreated samples was significantly $(\mathrm{P}<0.05)$ lower than control samples.

Table (6)

Effect of Oxytocin (2 IU/ml) on the seminal biochemical parameters following sperm activation without sperm preparation medium.

\begin{tabular}{|c||c||c||c||}
\hline \multirow{2}{*}{ Biochemical parameters } & \multirow{2}{*}{ Before activation } & \multicolumn{2}{c||}{ After activation* } \\
\cline { 3 - 4 } & & Control & OT-treated \\
\hline \hline Total Protein $(\mathrm{g} / 100 \mathrm{ml})$ & $4.80 \pm 0.74$ & $2.81 \pm 0.46$ & $2.85 \pm 0.40$ \\
\hline Cholesterol $(\mathrm{mg} / 100 \mathrm{ml})$ & $31.86 \pm 12.85$ & $20.54 \pm 9.13$ & $21.98 \pm 8.67$ \\
\hline \hline Calcium $(\mathrm{mg} / 100 \mathrm{ml})$ & $17.27 \pm 5.80$ & $14.17 \pm 2.98$ & $13.12 \pm 2.68$ \\
\hline \hline Creatine Kinase $(\mathrm{IU} / \mathrm{L})$ & $220.47 \pm 44.51$ & $166.22 \pm 33.83$ & $165.82 \pm 36.98$ \\
\hline \hline Fructose $(\mathrm{mg} / 100 \mathrm{ml})$ & $253.80 \pm 50.83$ & $188.22 \pm 45.22$ & $184.71 * * \pm 43.31$ \\
\hline
\end{tabular}

Values are means \pm standard deviation of means. *Significant differences $(P<0.001)$ in all the biochemical parameters between before and after activation. **Significant difference $(P<0.05)$.

When a comparison was made between the same activation technique with or without SPM, non-significant differences $(\mathrm{P}>0.05)$ were found in regard to levels of $\mathrm{TP}$ and cholesterol between the two preparation techniques in control and OT-treated samples as shown in (Fig.8 and 9) respectively, while level of calcium significantly decreased $(\mathrm{P}<0.05)$ following the use of SPM in the two groups
(Fig.10). The results also revealed that nonsignificant difference $(\mathrm{P}>0.05)$ was observed in regard to level of $\mathrm{CK}$ between the two preparation techniques in the two groups (Fig.11), while level of fructose significantly decreased $(\mathrm{P}<0.05)$ following the use of SPM in the two groups (Fig.12).

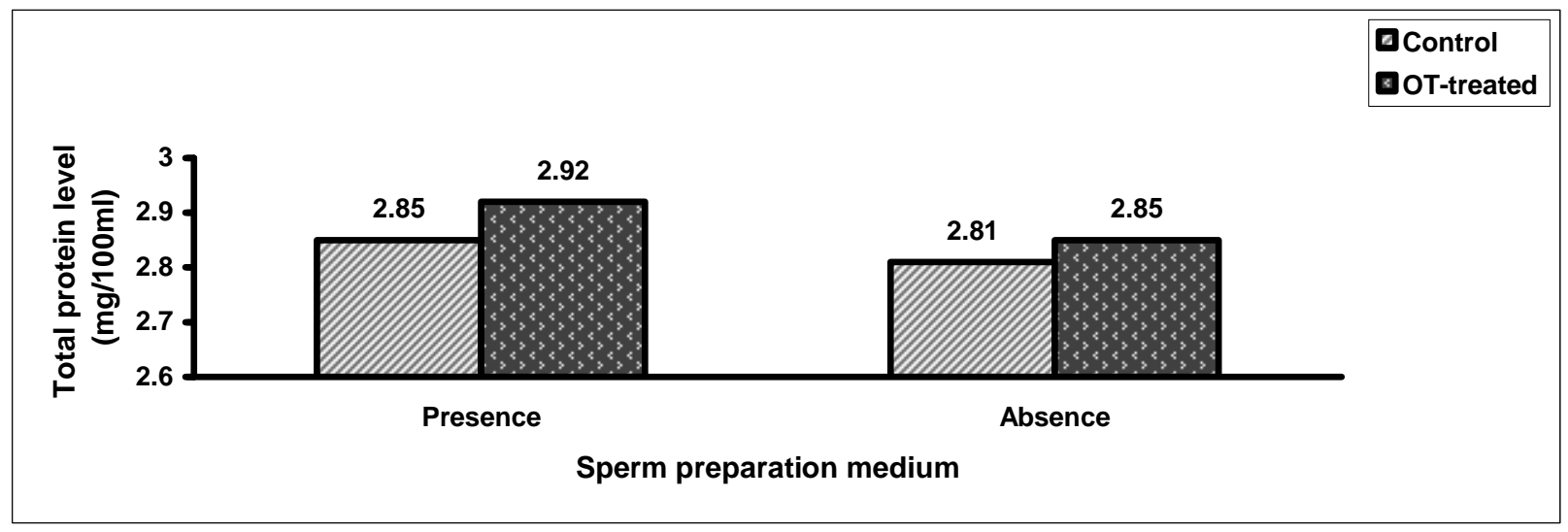

Fig. (8) : Level of total protein in the control and OT-treated samples following sperm activation divided according to presence and absence of sperm preparation medium.

- Non-significant difference $(P>\mathbf{0 . 0 5})$ from corresponding group. 


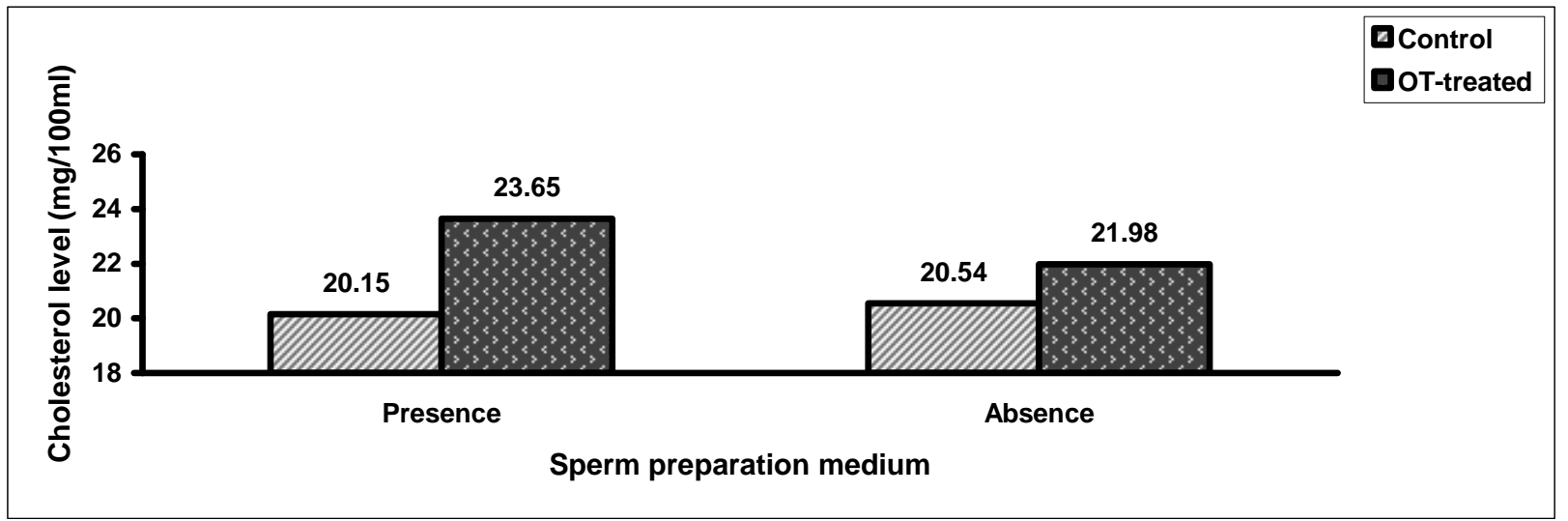

Fig. (9): Level of cholesterol in the control and OT-treated samples following sperm activation divided according to presence and absence of sperm preparation medium.

- Non-significant difference $(\mathbf{P}>\mathbf{0 . 0 5})$ from corresponding group.

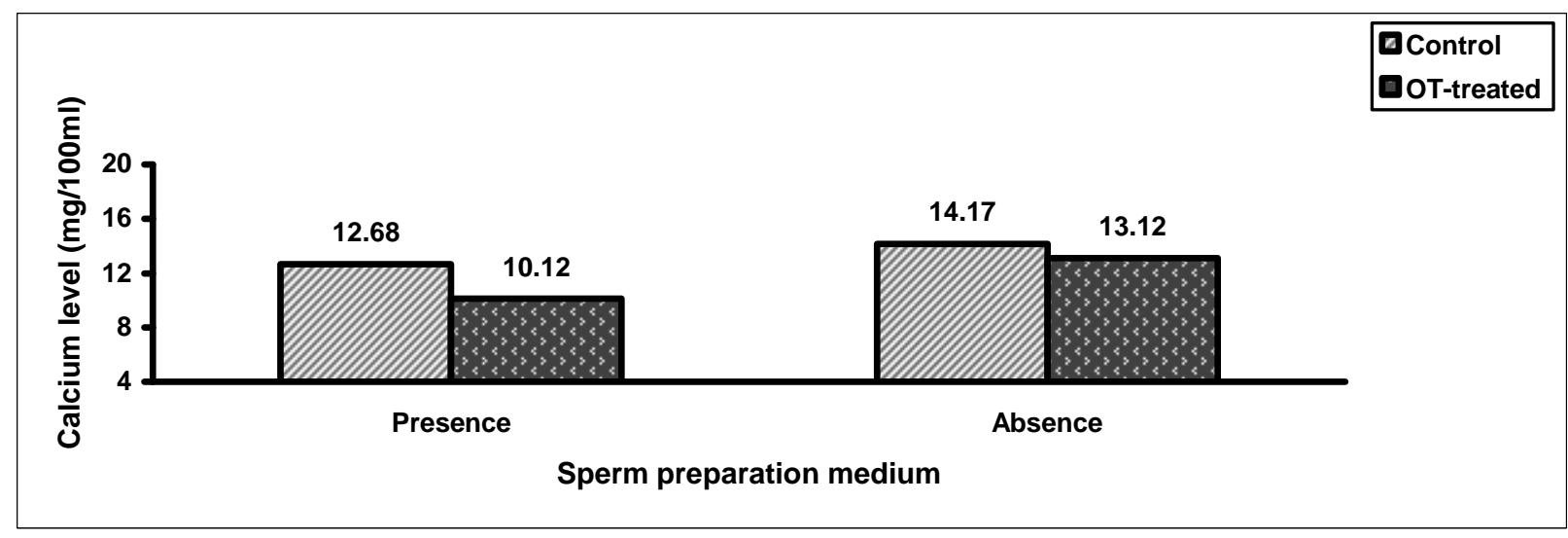

Fig.(10) : Level of calcium in the control and OT-treated samples following sperm activation divided according to presence and absence of sperm preparation medium.

•*Significant difference $(\mathbf{P}<0.05)$ from corresponding group.

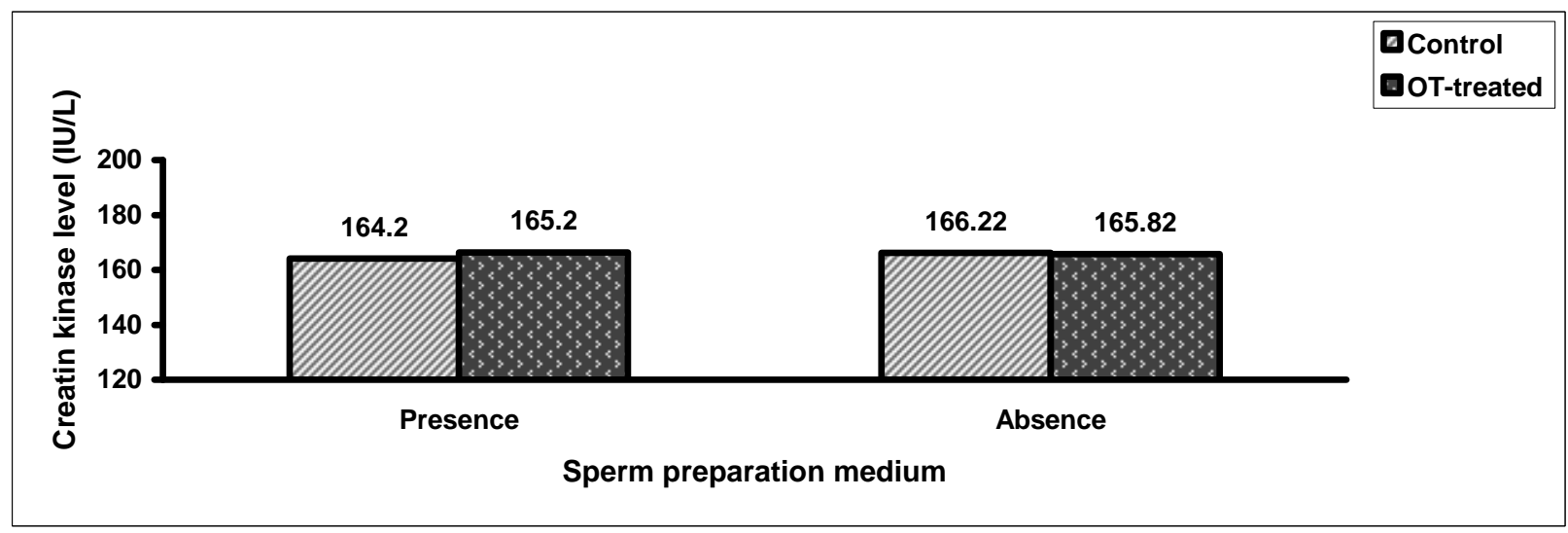

Fig.(11): Level of creatine kinase in the control and OT-treated samples following sperm activation divided according to presence and absence of sperm preparation medium.

-Non-significant difference $(P>\mathbf{0 . 0 5})$ from corresponding group. 


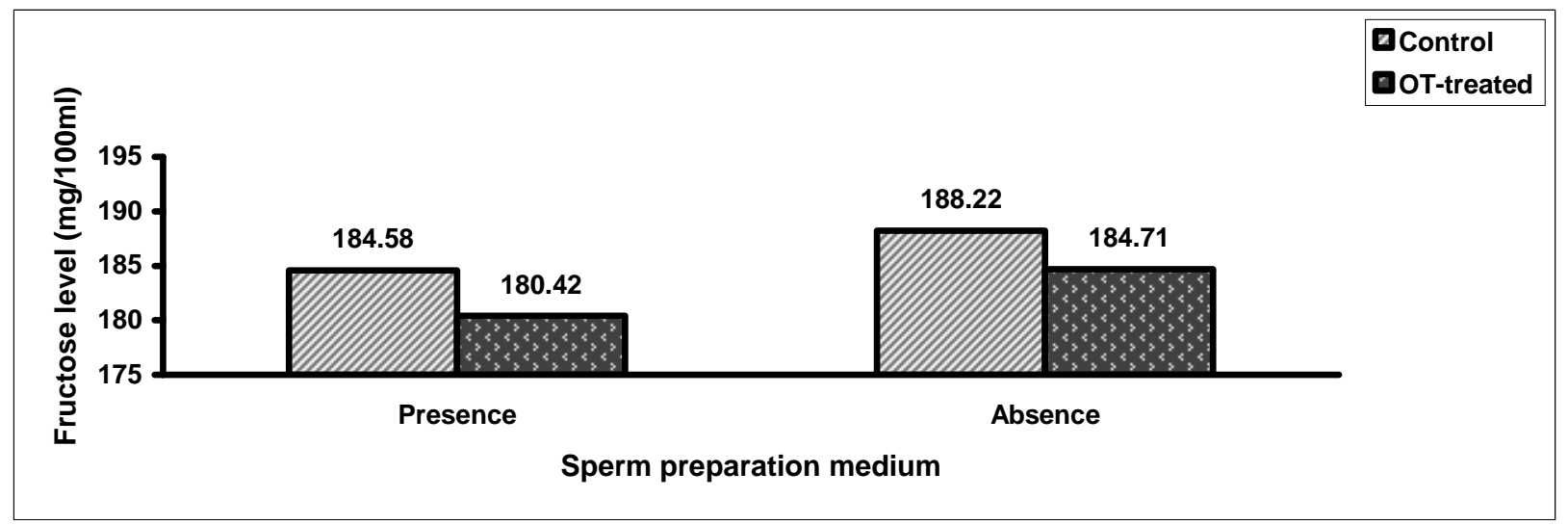

Fig.(12) : Level of fructose in the control and OT-treated samples following sperm activation divided according to presence and absence of sperm preparation medium.

- *Significant difference $(\mathbf{P}<0.05)$ from corresponding group.

\section{Discussion}

Regarding semen analysis of ninety asthenospermic patients, the results indicate a significant increase in liquefaction time associated with a significant decrease in semen volume as compared to the reported values in the available literature ${ }^{(11)}$. Inadequate liquefaction of the semen may indicate a deficiency of prostatic enzymes ${ }^{(19)}$. Low semen volume can be indicative of retrograde ejaculation, ejaculation duct obstruction, and androgen deficiency ${ }^{(20)}$. The mean of sperm concentration of the studied cases was within normal limit, majority of them had sperm concentration below the normal limit. The decline in sperm concentration may be due to the lifestyle risk factors such as: cigarette smoking, alcohol consumption, chronic stress, and nutritional deficiencies ${ }^{(21)}$. The low percentage of sperm motility and sperm grade activity of the semen samples in the present study may be due to many factors such as: spermatozoal structural defects, genital tract infection, antisperm antibodies, and partial ductal obstruction $^{(22)}$. The presence of abnormal sperm forms in the studied cases might reflect disturbances during spermiogenesis, spermiation, and sperm passage during epididymis ${ }^{(23)}$. Increase percentage of agglutinated sperm in the semen of the studied cases may attributed to infections of the male genital tract and presence of antisperm antibodies in the seminal plasma or to infections of the male genital tract. Mazumder and Levine ${ }^{(24)}$ found that infections of the male genital tract are associated with antisperm antibodies formation and sperm agglutination. Elevation of leukocytes and phagocytes concentrations of the semen samples above the normal limit stated by $\mathrm{WHO}^{(11)}$ can be due to a variety of pathologic changes. The previous reports showed that excessive presence of leukocytes in semen of the infertile men can interfere with the quality of the semen and more importantly with the functional status of sperm fertilizing ability ${ }^{(25 ; 26)}$.

The significant increase in sperm grade activity, when OT was added at concentration of $2 \mathrm{IU} / \mathrm{ml}$ and the tendency for a decrease in this parameter with increasing OT concentration are in agreement with a previous study ${ }^{(12)}$ who suggested that $2 \mathrm{IU} / \mathrm{ml}$ of OT is the best dose which exhibit varying degree of stimulation on sperm grade activity. In presence of SPM, the significant reduction observed in sperm concentration after the incubation period in the OT-treated and control samples may be due to semen dilution during sperm activation. The significant improvement observed in the percentage of sperm motility and sperm grade activity in both groups may be attributed to presence of SPM which consists of a basic salt solution and energy sources which cause an increase in sperm activity ${ }^{(27)}$. The results showed that OT caused an increase in sperm motility 
and sperm grade activity, this indicates that OT has got a stimulatory effect on sperm movement. In a previous study, Al-Abayachi ${ }^{(12)}$ concluded that OT increases sperm progressive movement (grade of activity) when proper artificial medium is available after half an hour, while it increases sperm vigorous (hyperactivity) movement in activated sperm after 2-4 hours of incubation. In absence of SPM, the results showed lack of any clear statistically significant change in all the semen parameter following the incubation period in both OT-treated and control groups except the sperm concentration which reduced significantly. On the other hand, the results showed that OT induced responses (although non significant) in both sperm motility and grade of activity as compared to the control. These results can be interpreted on the ground that sperm motility induced by OT require essential nutrients in SPM which can not be provided by normal saline alone. It is well known that hyperactive motility occurs when the sperm were incubated in culture medium that is a balanced salt solution containing energy providing substances such as lactate, pyruvate, glucose, and a protein such as albumin ${ }^{(28)}$.

Regarding the effect of OT on the seminal biochemical parameters, the results showed, in presence of SPM, a significant reduction observed in all the biochemical parameters after incubation period in OT-treated and control samples, this may be attributed to semen dilution as a result of addition of SPM, OT, and normal saline during sperm activation. The results revealed no significant differences in the level of TP between the OT-treated and control samples, while cholesterol level in OT-treated samples was significantly higher than the control samples. This finding suggests that OT may be caused loss of cholesterol from the plasma membrane of the sperm, because we found increase level of this component in the external medium. It has been reported that when sperm are incubated in a capacitating medium in vitro, the sperm cholesterol content gradually decreases ${ }^{(29 ; 30)}$. A significant decrease in level of calcium in the external medium of the OTtreated samples as compared with the control samples suggests that presence of OT combination with SPM may modify cellular calcium transport by incorporating into the sperm cell plasma membrane and transporting calcium across the plasma membrane, resulting in high intracellular calcium concentrations due to an influx of extracellular calcium. This finding suggests that OT stimulates human sperm motility at least in part by a mechanism which increased intracellular calcium concentration. It has been reported that the ability of the mature mammalian sperm to maintain a coordinated and forward motility is dependent upon intracellular free calcium ${ }^{(31)}$. When the level of $\mathrm{CK}$ was compared between the OT-treated group and control group, no significant differences were observed between the two groups. In a previous study, Huszar et $a l .{ }^{(32)}$ measured the value of sperm CK activity in the initial specimens and in the swim-up fractions of fertile and infertile men, they demonstrated that CK activities in the selfmigrated sperm fractions were significantly improved downward compared to the initial semen specimens. Considering the fructose level in the OT-treated and control samples, it is obvious that it was lower in the former group than in the later group. This finding may be explained on the ground that increased utilization of fructose by the activated sperm in the OT-treated samples as compared with the control samples. This finding also indicated that sperm of OT-treated samples were more active than control samples because the more active cells used more fructose ${ }^{(33)}$. In absence of SPM, a slight increase and a slight decrease (nonsignificant) in levels of cholesterol and calcium, respectively were observed in OT-treated samples as compared with the control samples, while the level of fructose in the OT-treated samples was significantly lower than that of the control samples.

It is of great interest to note that these findings provide another evidence for the role of OT as a stimulating agent to improve the sperm motility of the asthenospermic specimens. In the same time, these data revealed indirectly the importance of SPM in improving the motility 
characteristics of sperm since a comparison between the two cases (presence and absence of SPM) indicated that the most significant changes were noted only when SPM was used.

\section{Conclusions}

Addition of OT (2 IU/ml) to semen of asthenospermic patients caused a significant increase in the percentage of sperm motility and grade of activity, and presence of SPM was found to have synergistic action on the improvement of sperm motility characteristics. The mechanism of action of OT on human sperm and its stimulatory effect on sperm motility parameters may be due to two mechanisms:

a. Increasing $\mathrm{Ca}^{2+}$ transport across the plasma membrane that increase intracellular calcium concentration.

b. Modification of the cholesterol content of the plasma membrane that cause loss of cholesterol from the plasma membrane of the sperm.

\section{References}

[1] Macleod, J and Wang, Y. (1979): Male infertility potential in term of semen quality: A review of the past, a study of the present. Fertil. Steril., 31: 103-116.

[2] Bonde, J.P. (1999): Environmental Factors. In: Male Infertility: Clinical investigation, causes, evaluation and treatment. Comhaire, F.S. (ed). Chapman and Hall Medical. London, Glasgow, New York. PP. 267-284.

[3] Brackett, N.L.; Lynne, C.M.; Aballa, T.C. and Ferrell, S.M. (2000): Sperm motility from the vas deferens of spinal cord injured men is higher than from the ejaculate. J. Urology, 164: 712-715.

[4] Krausz, C.; Bonaccorsi, L.; Maggio, P.; Luconi, M.; Criscuoli, L.; Fuzzi, B.; Pellegrini, S.; Forti, G. and Baldi, E. (1996): Andrology: Two functional assays of sperm responsiveness to progesterone and their predictive values in in vitro fertilization. Hum. Reprod., 11: 1661-1667.

[5] Al-Sultani, Y.K.M. (1997): In vitro human sperm activation of infertile patients complaining from oligospermia and leukospermia by application of culture media and gonadotrotrophic hormones. Ph.D. Thesis, College of Science, Baghdad University.

[6] Brenner, S.H.; Lessing, J.B.; Schoenfeld, C.; Amelar, R.D.; Dubin, L. and Weiss, G. (1984): Stimulation of human sperm cervical mucus penetration in vitro by relaxin. Fertil. Steril., 42: 92-96.

[7] Tesarik, J.; Mendoza, C. and Carreras, A. (1992): Effect of phosphodiesterase inhibitors, caffeine and pentoxifylline on spontaneous and stimulus- induced acrosome reactions in human sperm. Fertil. Steril., 58: 185-190.

[8] Rees, J.M.; Ford, W.C.L. and Hull, M.G.R. (1990): Effect of caffeine and of pentoxifylline on the motility and metabolism of human spermatozoa. J. Reprod. Fertil., 90: 147-156.

[9] Bracho, G.E.; Fritch, J.J. and Tash, J.S. (1998): Identification of flagellar proteins that initiate the activation of sperm motility in vivo. Biochem. Biophys. Res. Commun., 242: 231-237.

[10] Ivell, R.; Balvers, M.; Rust, W.; Bathgate, R. and Einspanier, A. (1997): Oxytocin and male reproductive function. Adv. Exp. Med. Biol., 424: 253-264.

[11] World Health Organization (1992): Reference values of semen variables. In: WHO laboratory manual for the examination of human semen and semencervical mucus interaction. $3 \mathrm{rd}$ ed. Cambridge University Press. Cambridge.

[12] Al-Abayachi, M.A. (2003): Effect of oxytocin on human sperm activation in vitro. High Diploma Thesis, Institute for Embryo Research and Infertility Treatment, Baghdad University.

[13] Silverman, L.M.; Christenson, R.H. and Grant, G.H. (1986): Amino acids and proteins. In: Textbook of clinical chemistry. Tietz, N.W. (ed). W.B. Saunders company. Philadelphia. pp. 519.

[14] Richmond, W. (1973): Preparation and properties of cholesterol oxidase from 
Nocardia sp. and it's application to the enzymatic assay to total cholesterol in serum. Clin. Chem., 19: 1350-1356.

[15] Baginski, E.S.; Marie, S.S.; Clark, W.L. and Zak, B. (1973): Direct microdetermination of serum calcium. Clin. Chim. Acta., 46: 46-54.

[16] Kavanagh, J.P. and Darby, C. (1983): Creatine kinase and ATPase in human seminal fluid and prostatic fluid. J. Reprod. Fertil., 68: 51-56.

[17] Mann, T. (1948): Fructose and fructolysis in semen in relation to fertility. Lancet, 254: 446.

[18] Daniel, W.W. (1983): Biostatistics: A Foundation for Analysis in the Health Sciences. John Wiley and Sons, New York.

[19] Alexander, N.J. (1982): Male evaluation and semen analysis. Clin. Obstet. Gynecol., $25: 463-493$.

[20] Turek, P.J. (2000): Male Infertility. In: Smith's General Urology. Tanagho, E.A. and Mc Aninch, J.W. (eds). 15th ed.. The Mc Graw- Hill Companies. USA. pp. 750 787.

[21] De Celis, R.; Pedron-Nuevo, N. and FeriaVelasco, A. (1996): Toxicology of male reproduction in animals and humans. Arch. Androl., 37: 201-218.

[22] Sigman, M. and Howards, S.S. (1998): Male Infertility. In: Campbells' Urology. Walsh, P.C.; Retik, A.B.; Vaughan, E.D. and Wein, A.J. (eds). W.B. Saunders Company. USA. pp. 1287.

[23] Lenzi, A.; Landini, G.; and Picardo, M. (1998): A rationale for glutathione therapy. Debate: Is antioxidant therapy a promising strategy to improve human reproduction? Hum. Reprod., 13: 1415-1424.

[24] Mazumdar, S. and Levine, A.S. (1998): Antisperm antibodies: Etiology pathogenesis, diagnosis and treatment. Fertil. Steril., 70: 799-810.

[25] Wolff, H.; Politch, J.A.; Martinez, A.; Haimovici, F.; Hill, J.A. and Anderson, D.J. (1990): Leukocytopermia is associated with poor semen quality. Fertil. Steril., 53: 528536.
[26] Trum, J.W.; Mol, B.W.; Pannekock, Y.; Spanjaard, L.; Wertheim, P.; Blaker, O.P. and Van der Veen, F. (1998): Value of detecting leukocytospermia in the diagnosis of genital tract infection in subfertile men. Fertil. Steril., 70: 315-319.

[27] Quinn, P.; Kerin, J.F. and Warnes, G.M. (1985): Improved pregnancy rate in human in vitro fertilization with the use of a medium based on the composition of human tubal fluid. Fertil. Steril., 44: 493-498.

[28] Ravnik, S.E.; Zarutskie, P.W. and Muller, C.H. (1992): Purification and characterization of a human follicular fluid lipid transfer protein that stimulates human sperm capacitation. Biol. Reprod., 47: 11261133.

[29] Go, K.J. and Wolf, D.P. (1985): Albuminmediated changes in sperm sterol content during capacitation. Biol. Reprod., 32: 145153.

[30] Zarintash, R.J. and Cross, N.L. (1996): The unesterified cholesterol content of human sperm regulates response of the acrosome to the agonist, progesterone. Biol. Reprod., 55: 19-24.

[31] Breitbart, H.; Rubinstein, S. and NassArden, L. (1985): The role of calcium and calcium-ATPase in maintaining motility in ram spermatozoa. J. Biol. Chem., 260: 11548-11553.

[32] Huszar, G.; Vigue, L. and Corrales, M. (1990): Sperm creatine kinase activity in fertile and infertile oligospermic men. J. Androl., 11: 40-46.

[33] Biswas, S.; Ferguson, K.M.; Stedronska, J.; Baffoe, G.; Mansfield, M.D. and Kosbab, M.H. (1978): Fructose and hormone levels in semen: The correlation with sperm counts and motility. Fertil. Steril., 30: 200204.

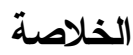

تم فحص عينات المني لــ90 مريضاً يعانون من وهــن

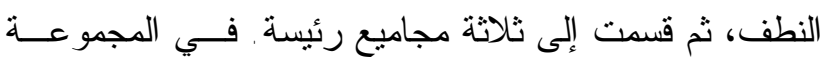

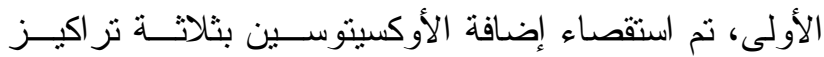


6,2,4 وحدة دولية/مل) مع وسط تحضــير النطــف، وقــــ

استخدمت التغير ات في اختبار ات وظيفة النطف وكيمياحياتية

المني كمؤشر لتأثير الإضـافة. أظهرت النتائج زيادة معنويـــة

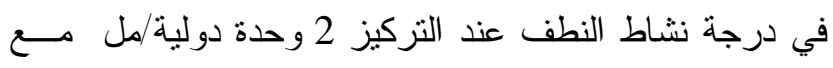

الميل إلى نتاقص هذا المعيار الحركي في التركيــز الأعلــى

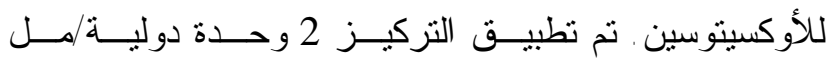

للاوكسيتوسين مع وجود وسط تحضير النطف وعدم وجــوده

في المجموعتين الثانية و الثالثة، على التو الي . عند وجود وسط تحضير النطف، لوحظت زيادة معنوية في خصائص الحركة (النسبة المئوية للنطف المتحركة ودرجة نشاط النطف) . أمسـا عند غياب وسط تحضير النطف، أظهرت النتائج عدم حدوث أي تغيير معنوي و اضح في هذين المعيارين . نتشير هذه النتائج

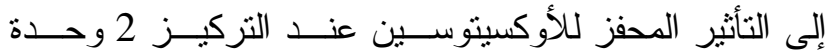
دولية/مل على خصائص حركة النطف، وقــــ أدى اســتعمال وسط تحضير النطف إلى دعم ذلك التأثير . تم قيــاس مســتوى البــروتين الكلــي، الكوليسـتيرول،

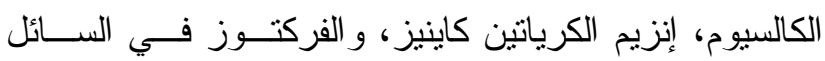
المنوي وفي الجزء الرائق من عالق النطــف فـــي عينـات

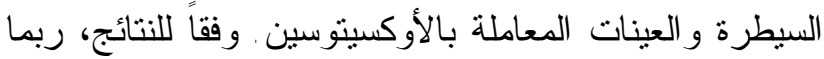
يكون الأوكسيتوسين سبياً في فقدان الكوليستيرول من الغشــاء

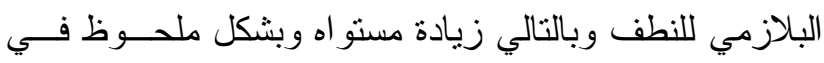

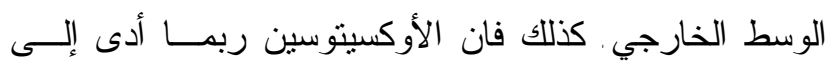

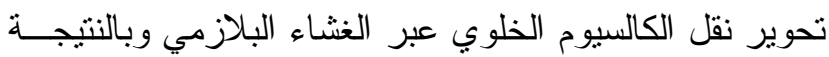
زيادة نركيز الكالسيوم داخل الخلية و انخفاض مستو اه وبشكل معنوي ملحوظ في الوسط الخارجي. بالإضافة إلى الانخفاض المعنوي الملحوظ في مستوى الفركتوز في الوسط الخارجي. 